\title{
Lap-joint testing of precoated steel materials
}

\author{
B. Chico*, D. de la Fuente*, M. Morcillo*, E. Otero* and J.A. González*
}

\begin{abstract}
In industry, particularly in the building construction, lap-joint technology for precoated steel sheet materials has undergone rapid development. However, standars for lap-joint testing are lacking. This work analyses the behaviour of four precoated steel materials commonly used in the building industry: $55 \% \mathrm{Al}-\mathrm{Zn}$ and hot dip galvanized, painted and unpainted. Two-year atmospheric exposure tests have been carried out in Madrid and Avilés (Spain), complemented by accelerated weathering tests in climatic cabinets. The latter have consisted of two salt fog/humidity/drying cycles: VDA cycle 621-415 and the "CENIM cycle", which has been designed to adequately simulate the behaviour of materials in this type of joints.
\end{abstract}

Keywords Lap-joint testing. Precoated Steel. Atmospheric corrosion. Accelerated weathering tests.

\section{Ensayos en uniones solapadas de aceros pre-recubiertos}

\begin{abstract}
Resumen En la industria en general y, particularmente, en la industria de la construcción, las tecnologías sobre uniones solapadas han experimentado un rápido desarrollo. Sin embargo, no son abundantes los ensayos para este tipo de uniones. Este trabajo analiza el comportamiento de cuatro materiales de acero pre-recubierto comúnmente usados en la industria de la construcción: $55 \% \mathrm{Al}-\mathrm{Zn}$ y galvanizado por inmersión en caliente, con recubrimiento orgánico y sin él. Se han realizado ensayos de exposición natural durante dos años en las atmósferas de Madrid y Avilés (España), complementados con ensayos de envejecimiento acelerado en cámaras climáticas. En estos últimos se han ensayado dos ciclos de proyección niebla salina/humedad/secado: ciclo VDA 621-415 y un ciclo desarrollado en el CENIM diseñado para simular adecuadamente el comportamiento de los materiales en este tipo de uniones.
\end{abstract}

Palabras clave Ensayos en unión solapada. Acero pre-recubierto. Corrosión atmosférica. Ensayos de envejecimiento acelerado.

\section{INTRODUCTION}

The adoption of designs involving the use of lapjoints is becoming increasingly common in different industries such as car manufacturing, building, aeronautics, etc.

The technology of precoated products in the steel industry has undergone a fast development in the last decade, producing higher quality materials. An example of this application can be seen in the automobile industry, with an increased use of precoated steel in lap or hem joints in manufactured vehicles.

There is also known to be an increasing use of precoated steel (painted or not) in the building industry, e.g. in the construction of large sheds and buildings, where lapping between plates is commonplace.

However, metallic sheets assembled by lapjoints are prone to suffer several corrosion processes: crevice corrosion, galvanic corrosion (in the case of unlike materials), etc, so the need to carry out laboratory tests in order to anticipate in practice the behaviour of this type of joints.

In the bibliographic review, which has been undertaken, no widely used international standards have been found which define in detail how to carry out this type of tests. Thus researchers have considered a variety of testing specimens and experimental conditions ${ }^{[1-5]}$. Only the European Coil Coating Association (ECCA), in its test method T19 ${ }^{[6]}$ for atmospheric tests, uses a panel

(*) Centro Nacional de Investigaciones Metalúrgicas (CENIM), (CSIC), Avda. Gregorio del Amo, 8. 28040 Madrid (España). 
design which includes a lap-joint. Similarly, the German specification VDA $621-415^{[7]}$, on the accelerated ageing of anti-corrosion coatings in the automobile industry, contains lap-joint designs.

In previous studies of the authors, in which conventional accelerated tests were carried out, a delay in the deterioration of the lapped zone was generally observed in comparison with the nonlapped zone, a situation which does not correspond with what frequently occurs in the aggressive atmospheres and in other real situations. These studies showed that the conventional accelerated corrosion tests are inadequate for correctly simulating the negative effect of lap-joints.

The authors of this paper have carried out a study in depth about the "Factors influencing the corrosion behaviour of coated steel sheets in lap joints" ${ }^{\text {"[8] }}$. Likewise, one of the authors of this paper, B. Chico, has carried out her Ph-D thesis about this subject $^{[9]}$. The present paper is based on a new accelerated test in lap-joints designed by the authors.

This work analyses the behaviour of four materials commonly used in the building industry: $55 \% \mathrm{Al}-\mathrm{Zn}$ and hot dip galvanized, painted and unpainted. Two-year atmospheric exposure tests have been carried out in Madrid and Avilés (Spain), complemented by accelerated weathering tests in climatic cabinets.

The latter have consisted of two salt fog/humidity/drying cycles: VDA cycle 621-415 [7] and the "CENIM cycle", which has been designed to adequately simulate the behaviour of materials in this type of joints.

\section{EXPERIMENTAL}

Table I shows the characteristics of the precoated steel materials tested.

\subsection{Atmospheric exposure tests}

The test specimens of the different materials were exposed for two years in atmospheric testing stations of Madrid and Avilés. The main characteristics of the stations are presented in table II. Figure 1 shows the lapped panel design used for this type of tests ${ }^{[1]}$.

Initially, test specimens were obtained in the form of single $75 \times 250 \mathrm{~mm}$ panels. Lapped specimens were assembled by vertically overlapping pairs of panels by $25 \mathrm{~mm}$. Lapped pairs were joined by aluminium rivets. The specimens
Table I. Materials characteristics

Tabla I. Características de los materiales

\begin{tabular}{|c|c|c|c|}
\hline \multicolumn{4}{|c|}{ Coating } \\
\hline \multicolumn{2}{|l|}{ Metallic } & \multicolumn{2}{|c|}{ Organic } \\
\hline Type & $\begin{array}{c}\text { Average } \\
\text { thickness, } \\
\mu \mathrm{m}\end{array}$ & $\begin{array}{c}\text { Type prime/ } \\
\text { Topcoat }\end{array}$ & $\begin{array}{c}\text { Average } \\
\text { thickness, } \\
\mu \mathrm{m}\end{array}$ \\
\hline $55 \% \mathrm{Al}-\mathrm{Zn}$ & 21 & - & - \\
\hline Hot-dip galvanized & 16 & - & - \\
\hline $55 \% \mathrm{Al}-\mathrm{Zn}$ & 21 & Epoxy/polyester & $4 / 27$ \\
\hline Hot-dip galvanized & 28 & $\begin{array}{l}\text { Polyurethane/ } \\
\text { Special Polyester }\end{array}$ & $4 / 19$ \\
\hline
\end{tabular}

Table II. Corrosivity characteristics of test sites

Tabla II. Características de corrosividad de las estaciones de ensayo

\begin{tabular}{|c|c|c|}
\hline & Avilés & Madrid \\
\hline Time of wetness (annual fraction) & 0.603 & 0.155 \\
\hline Chloride deposition rate $\left(\mathrm{mg} \cdot \mathrm{m}^{-2} \cdot \mathrm{d}^{-1}\right)$ & 66.6 & 0.9 \\
\hline $\mathrm{SO}_{2}$ deposition rate $\left(\mathrm{mg} \cdot \mathrm{m}^{-2} \cdot \mathrm{d}^{-1}\right)$ & 19.2 & 36.6 \\
\hline ISO corrosivity category ${ }^{*[10]}$ & C4 & $\mathrm{C} 2$ \\
\hline Mild steel corrosion rate $\left(\mu \mathrm{m} \cdot \mathrm{y}^{-1}\right)$ & 71.1 & 18.5 \\
\hline Zinc corrosion rate $\left(\mu \mathrm{m} \cdot \mathrm{y}^{-1}\right)$ & 2.55 & 0.40 \\
\hline
\end{tabular}

* Based on environmental parameters

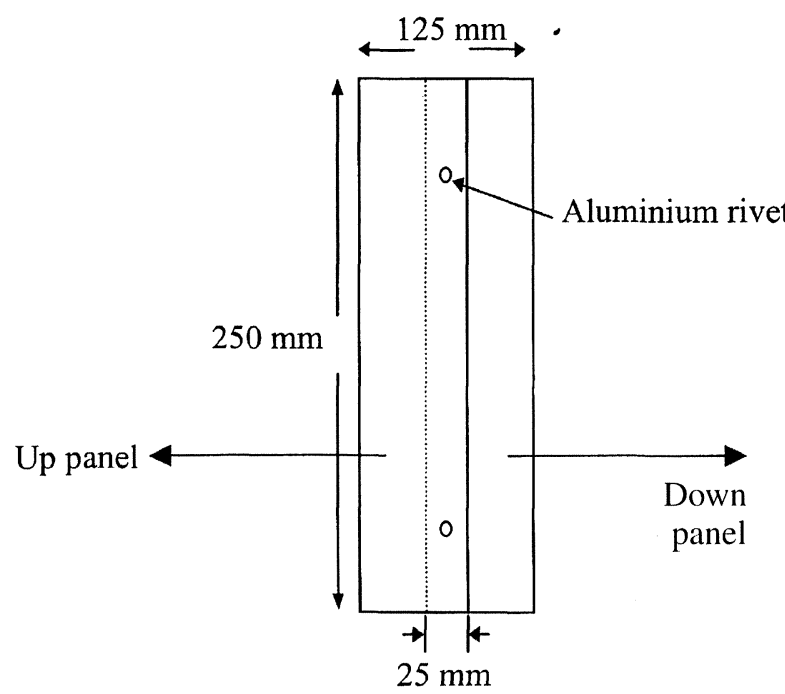

Figure 1. Lapped specimen used for atmospheric exposure tests.

Figura 1. Probeta solapada utilizada para los ensayos de exposición atmosférica.

Rev. Metal. Madrid Vol. Extr. (2003) 143-150 
were exposed to the atmosphere with the overlap running vertically, with the left part over the right, following the criteria of the European Coil Coating Association (ECCA $)^{[6]}$.

\subsection{Accelerated tests}

The basic design of lapped panels for this type of experimentation is shown in figure 2. Specimens of $125 \times 50 \mathrm{~mm}$ were prepared, formed by the overlapping of single plates of $75 \times 50 \mathrm{~mm}$, leaving an overlap length of $25 \mathrm{~mm}$. Lapped pairs were joined by aluminium rivets (Fig. 2 (a)). A set of accelerated tests were focused in order to discern the effect of a controlled gap in the opening of the lap-joint (i.e. $200 \mu \mathrm{m}$ ) since the riveted joint does not allow to control the mentioned gap (theorically $0 \mu \mathrm{m}$ ). The control of the crevice width could be achieved by means of lengths of adhesive tape of the mentioned thickness at the side edges of the lap, establishing the lap-joint by means of plastic clips (Fig. 2 (b)).

The lapped panels were placed in chambers with the overlap in horizontal position and with the opening facing upwards, in order to favour the penetration of aggressive agents in the crevice of the lap-joint.

After several preliminary tests ${ }^{[8}$ and 11$]$, CENIM developed a specific accelerated corrosion test in order to reproduce what normally occurs in practice: premature degradation of the material in the lap-joint.

The CENIM cycle (weekly) consisted of:

- 1 day of constant humidity condensation (ASTM D 4585) $^{[12]}$.

- $8 \mathrm{~h}$ of salt fog (ASTM B 117) ${ }^{[13]}$.

- $88 \mathrm{~h}$ in climatic chamber at $20{ }^{\circ} \mathrm{C}$ and $95 \%$ $\mathrm{RH}$.

$-2 \mathrm{~d}$ at room temperature and $\mathrm{RH}$.

The tests were carried out in parallel with the VDA 621-415 cyclic test for comparative purposes $^{[7]}$. The VDA $621-415$ standard, used as an accelerated corrosion test for automotive body materials, uses as test specimens lapped panels. This weekly cycle, modified slightly in order not to have visit the laboratory during the weekends, consisted of:

- 1 day of salt fog, according to ASTM B $117^{[13]}$.

- 4 days of humidity condensation according to KFW DIN $50017^{[14]}$. Each day consisting of $8 \mathrm{~h}$

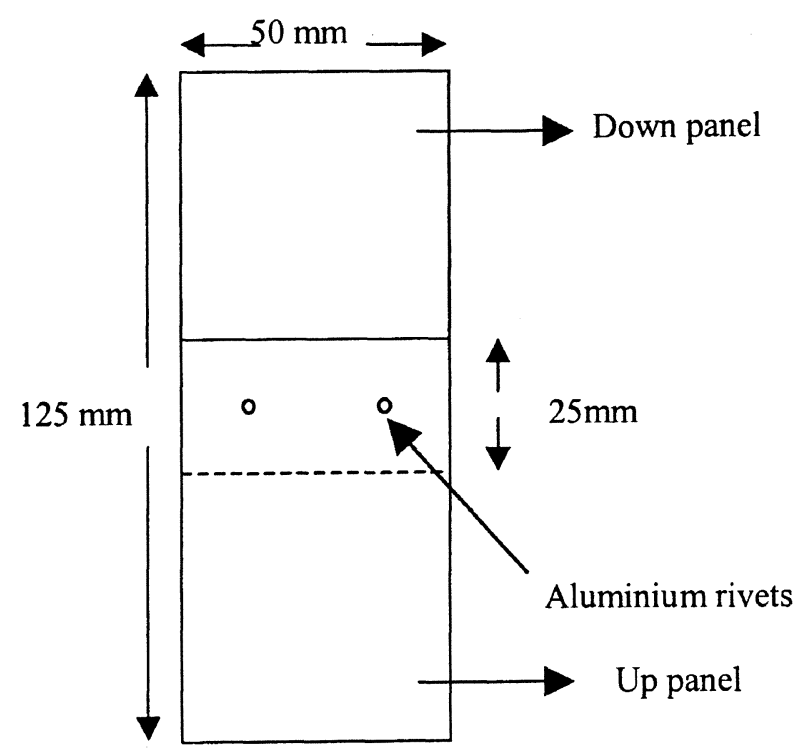

(a)

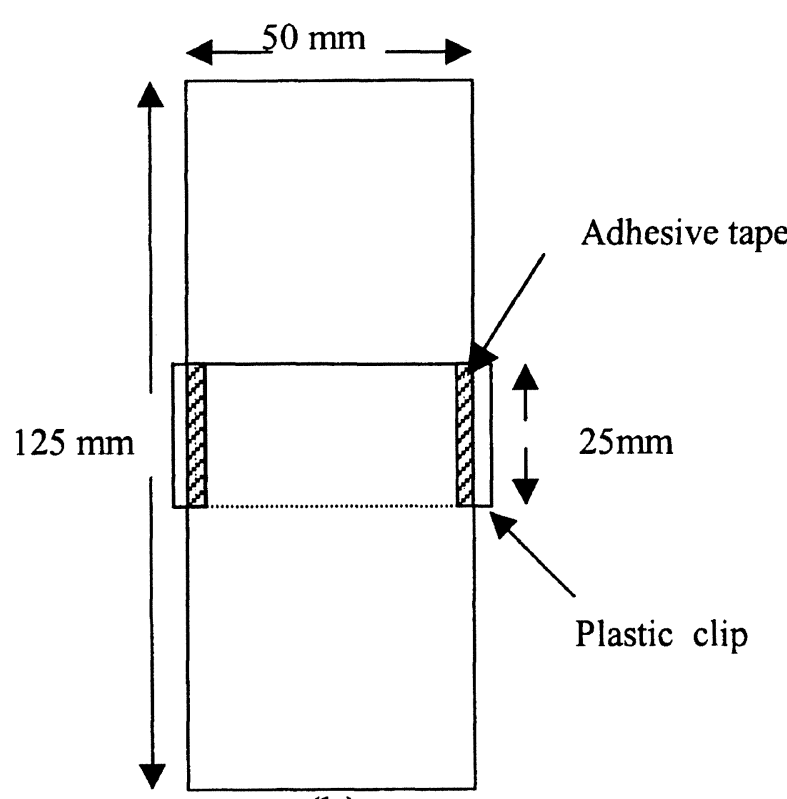

(b)

Figure 2. Lapped specimens used for accelerated tests.

Figura 2. Probetas solapadas utilizadas para los ensayos acelerados.

of heating with the chamber door closed (humidity stage), followed by $16 \mathrm{~h}$ without heating and with the chamber door open (drying stage). The final day consists of $4 \mathrm{~h}$ of drying instead of the $16 \mathrm{~h}$ indicated by the standard.

- $2.5 \mathrm{~d}$ of drying in laboratory conditions, instead of the two days indicated by the standard. 


\section{RESULTS}

\subsection{Atmospheric exposure tests}

Figure 3 shows the aspect of tested materials after two years of exposure in the atmospheres of Madrid and Avilés.

\section{- Metallic Coatings}

In the lapped zone, the best behaviour is observed with the $55 \% \mathrm{Al}-\mathrm{Zn}$ material. This material appears unaltered after two years, conserving its initial shine even in the atmosphere of Avilés, which showed the highest corrosivity. In this atmosphere there is only slight loss of shine close to the openings of the lap-joint. The hot-dip galvanized material in the lap-zone only present a practically generalized darkening of the surface and white corrosion on isolated zones of the surface. White zinc corrosion products were identified as basic zinc carbonate $\left[\mathrm{Zn}_{4} \mathrm{CO}_{3}(\mathrm{OH})_{6} \cdot \mathrm{H}_{2} \mathrm{O}\right]$ and $\alpha \mathrm{Fe}$. The higher attack observed in the darker zones seems to lead to thicker corrosion products so $\alpha$ Fe was not detected.

In the non-lapped zone, the $55 \% \mathrm{Al}-\mathrm{Zn}$ and hot-dip galvanized materials only present generalized darkening (and loss of initial shine) of the surface.

- Metallic + Organic Coatings

After two years of atmospheric exposure, the organic coatings applied on $55 \% \mathrm{Al}-\mathrm{Zn}$ and hot-dip galvanized are seen to be without significant defects.
$55 \% \mathrm{Al}-\mathrm{Zn}$
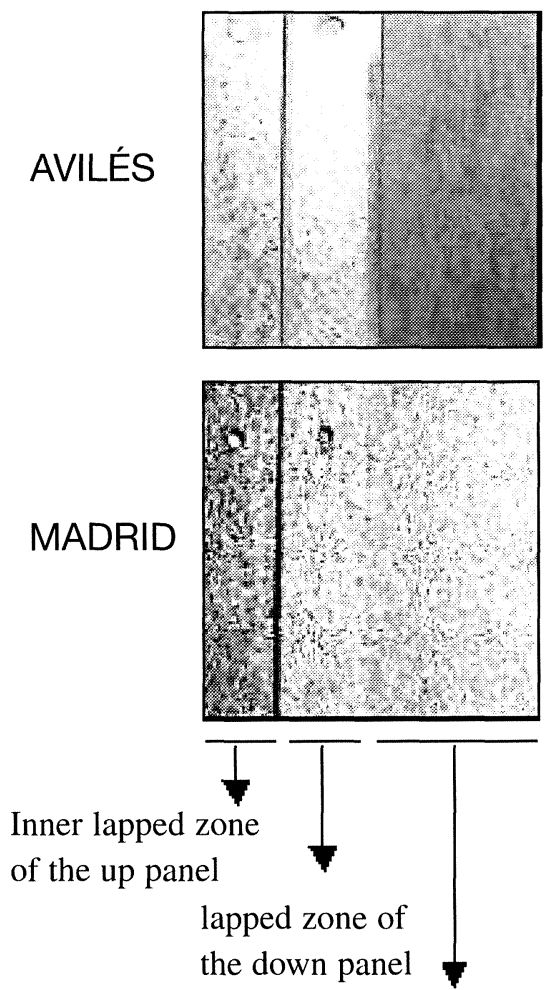

not lapped zone

of the down panel
Hot-dip galvanized
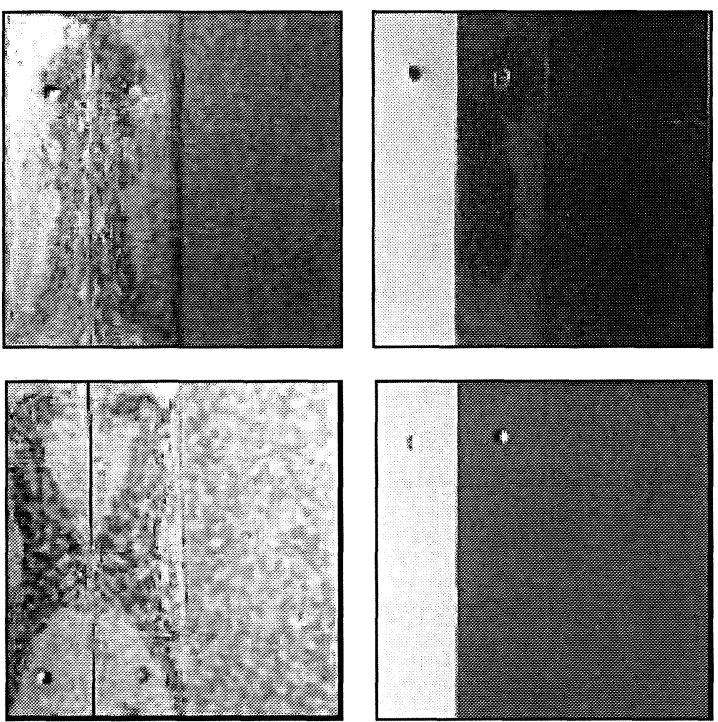

\section{Hot-dip galvanized + organic coating}
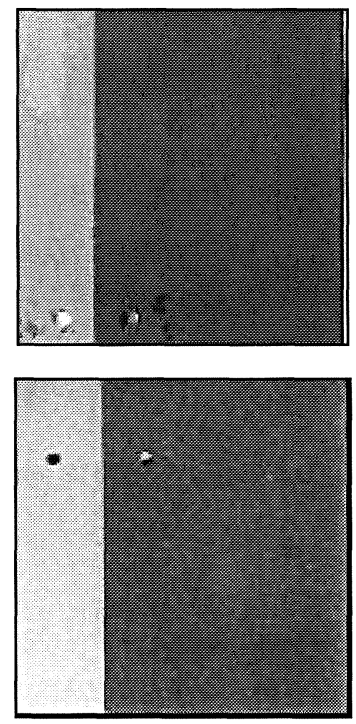

Figure 3. Photographs showing the state presented by steel specimens precoated with metallic coatings and metallic + organic coatings after two years of exposure in the atmospheres of Madrid and Aviles, after dismantling of the lap-joint.

Figura 3. Fotografías mostrando el aspecto que presentaban las probetas, una vez desmontada la unión solapada, de acero recubierto con recubrimientos metálicos y recubrimientos metálico + orgánico después de dos años de exposición en las atmósferas de Madrid y Avilés. 


\subsection{Accelerated tests}

Figures 4 and 5 show the tested materials after 10 CENIM and VDA cycles.

- Metallic coatings

$2,4,6,10$ and 20 were carried out. In view of the results obtained, 10 testing cycles is sufficient time to evaluate the behaviour of these materials and both cycles, CENIM and VDA, promote a notable attack in the lapped zone, more $(55 \% \mathrm{Al}-\mathrm{Zn})$ or less (hot-dip

\section{$55 \%$ Al-Zn}
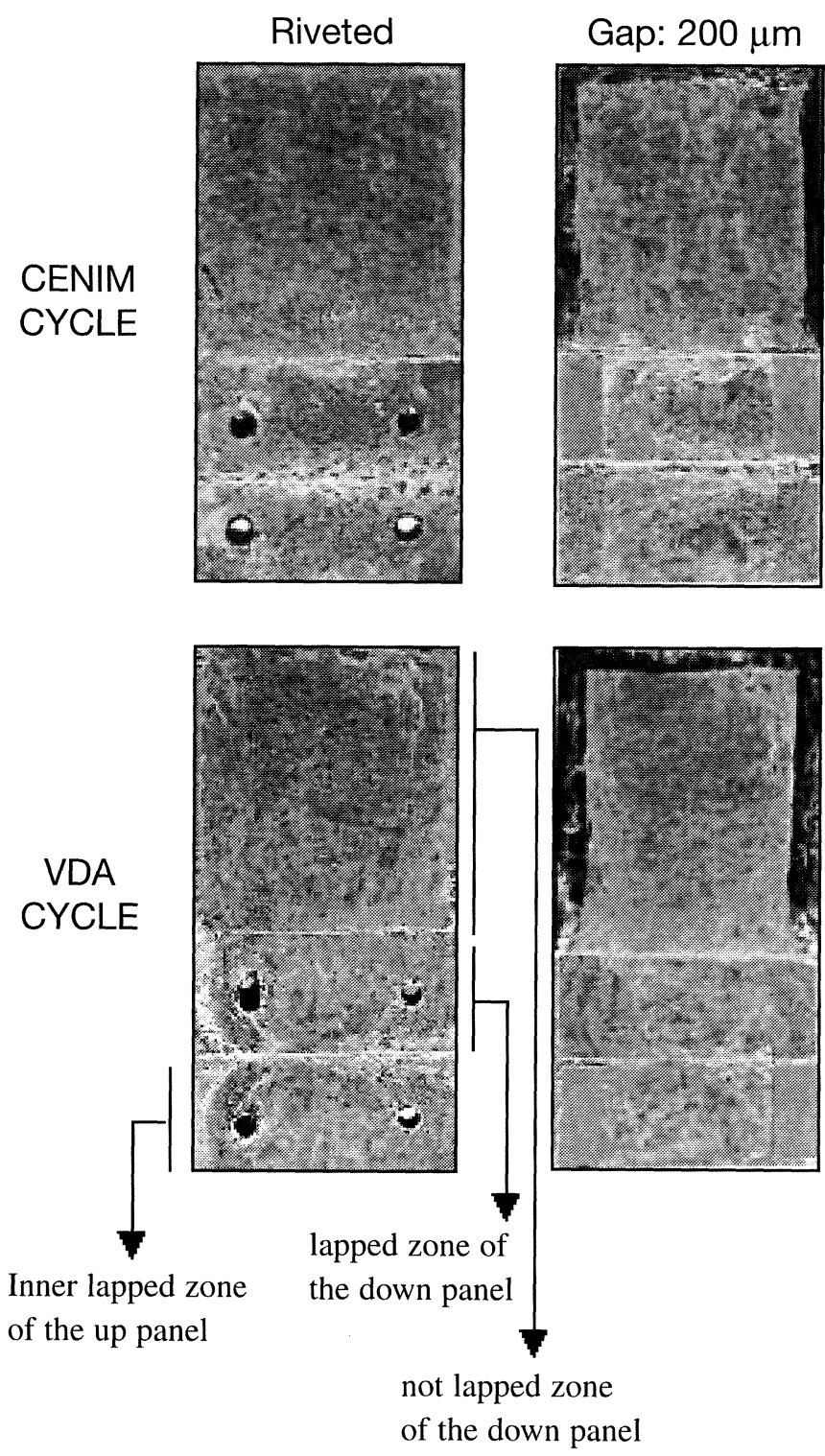

galvanized) than in the non-lapped zone. The separation of $200 \mu \mathrm{m}$ contributes to a greater attack of the material in the lapped zone, particularly in the case of the hot-dip galvanized material.

- Metallic + organic coatings

10 testing cycles is sufficient time to evaluate the behaviour of these materials and both cycles, CENIM and VDA, promote a greater attack in the lapped zone than in the nonlapped zone. The lap separation of $200 \mu \mathrm{m}$

\section{Hot dip galvanized}
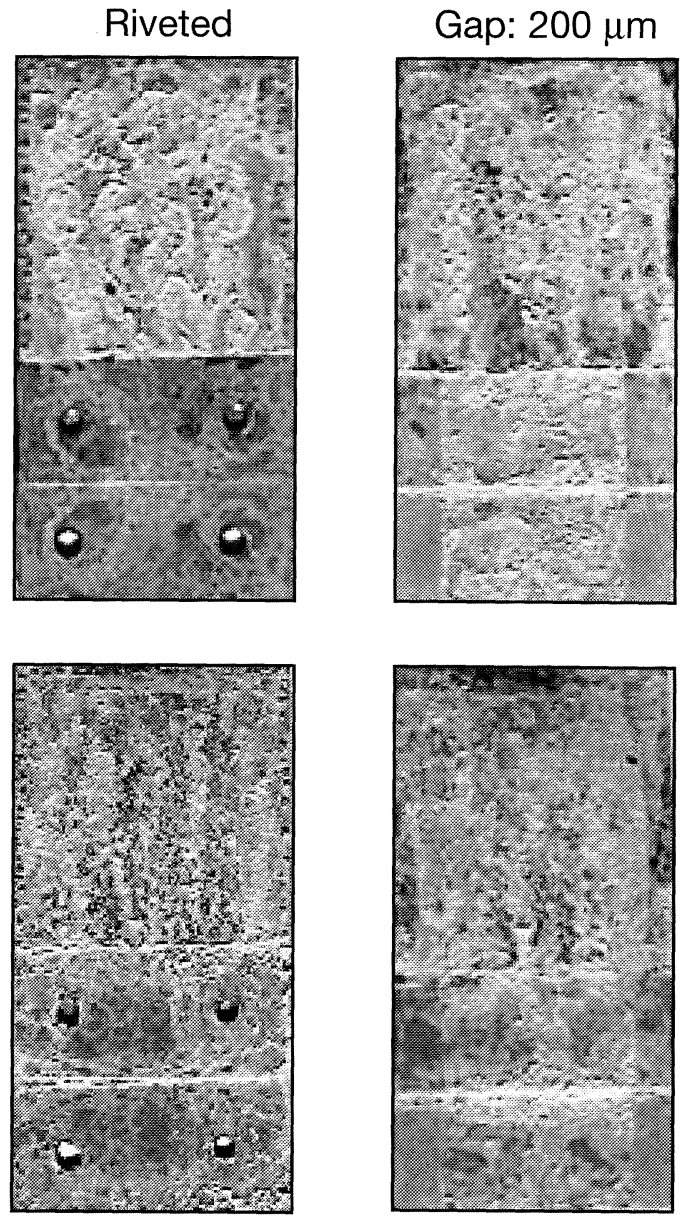

Figure 4. Aspect of the $55 \% \mathrm{Al}-\mathrm{Zn}$ and hot-dip galvanized materials in the lapped and non-lapped zones after 10 CENIM and VDA cycles, after dismantling of the lap-joint.

Figura 4. Aspecto que presentaban, una vez desmontada la unión solapada, los materiales 55 \% Al-Zn y galvanizado por inmersión en caliente en las zonas solapada y no solapada después de 10 ciclos CENIM y VDA. 


\section{$55 \% \mathrm{Al}-\mathrm{Zn}+$ organic coating}

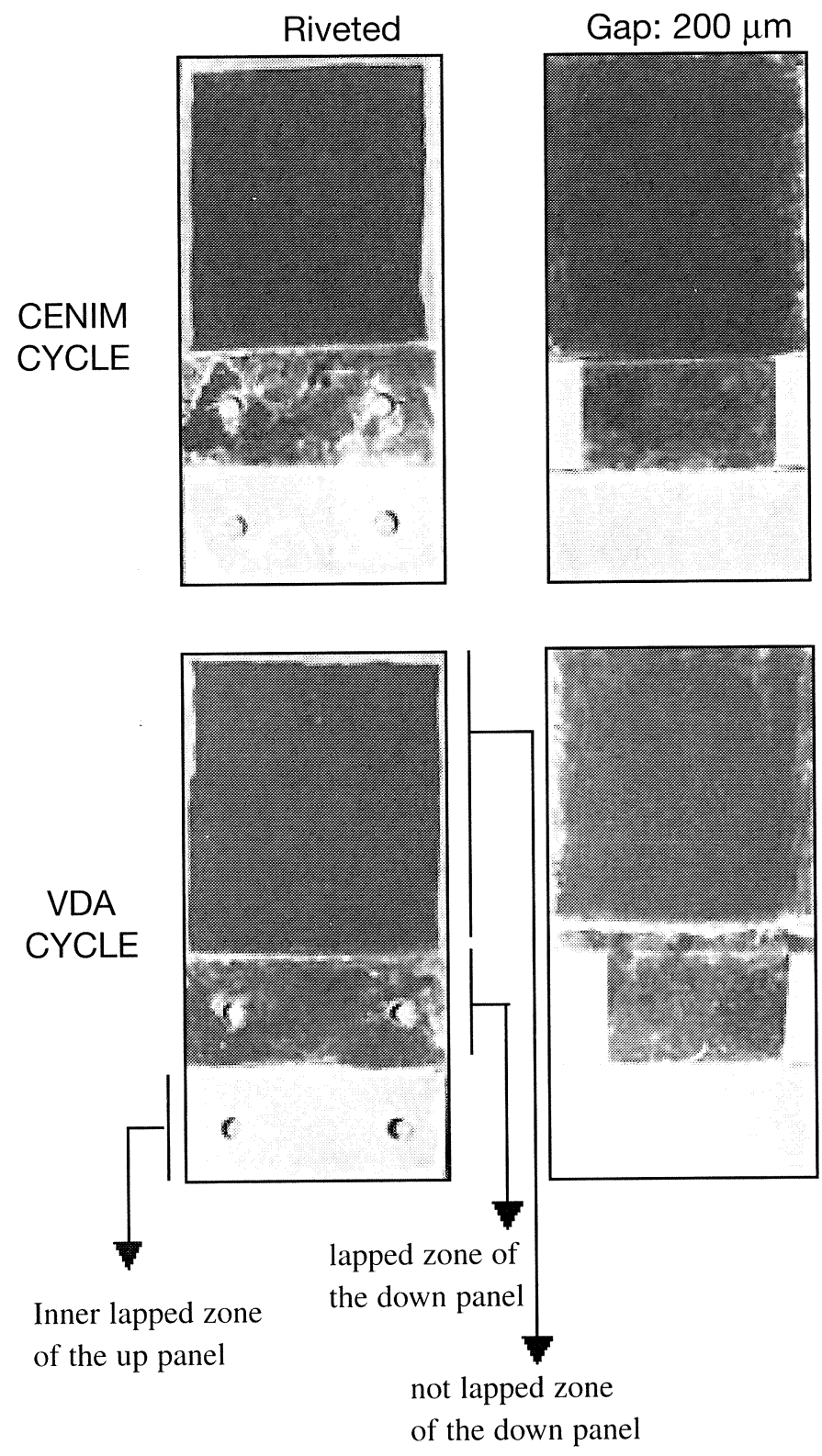

\section{Hot-dip galvanized + organic coating}
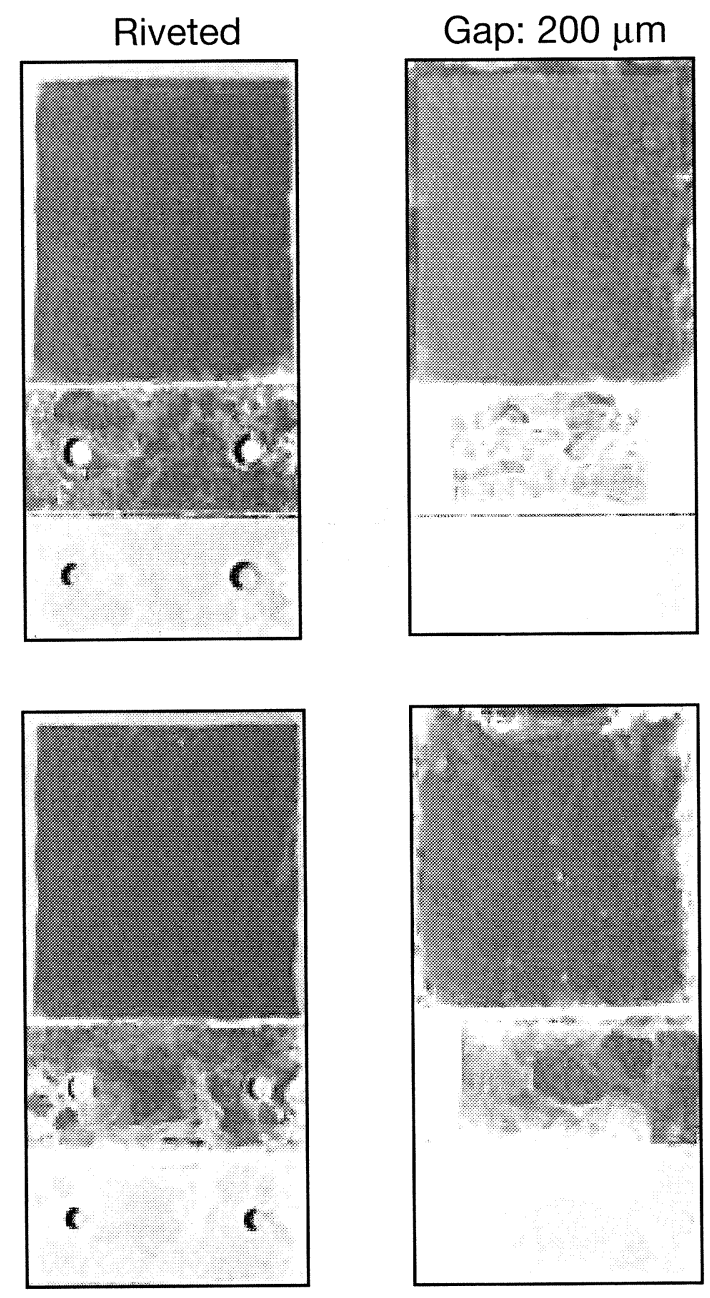

Figure 5. Aspect of the mixed (metallic + organic) materials in the lapped and non-lapped zones after 10 CENIM and VDA cycles, after dismantling of the lap-joint.

Figura 5. Aspecto que presentaban, una vez desmontada la unión solapada, los materiales mixtos (metálico + orgánico) en las zonas solapada y no solapada después de 10 ciclos CENIM y VDA.

accelerates the deterioration of the prepainted galvanized material in the lapped zone. With the prepainted $55 \% \mathrm{Al}-\mathrm{Zn}$, on the other hand, it seems to delay the attack.

\section{DISCUSSION}

The philosophy which inspired the development of this accelerated corrosion test was based on the following premises: 
- that the test should promote an acceleration of the attack of the material in the interior of the crevice formed in the lap-joint.

- that the test should be sufficiently aggressive so that while complying with the first requisite it should not cause excessive delay in the degradation of the material in the lapped zone compared with deterioration in the non-lapped zone, thus simulating the process which generally occurs in practice.

- that the test should be applicable to a wide range of coating materials. In our case metallic coatings, with or without organic finishing coatings.

In the development of this new test the following aspects were considered: design of the test specimen and testing conditions.

\subsection{Design of the test specimen}

The shape and dimensions of the test specimens used from the outset in this study were considered adequate. The specimens of $125 \times 50 \mathrm{~mm}$ (Fig. 1) were formed by the lapping of single plates of $75 \times 50 \mathrm{~mm}$ taken from coils manufactured by continuous strip processes, leaving a lap length of $25 \mathrm{~mm}$ (lapped area / non-lapped area ratio of 0.25). Lapped pairs were joined by aluminium rivets spaced $30 \mathrm{~mm}$ apart.

The attack of the material in the lap-joint increases with the lap separation. A crevice width of $200 \mu \mathrm{m}$ can be sufficient for this purpose. In these cases the control of the crevice width can be achieved by means of lengths of adhesive tape (better than non-adherent plastic) at the side edges of the lap, establishing the lap-joint by means of plastic clips (Fig. 2(b)). In the case of passive materials (aluminium and its alloys, stainless steel, etc.) it is not advisable to increase the crevice thickness, if what is wished is precisely to cause failure. In these cases riveting is preferable, as these can facilitate the deoxigenation of the crevice and promote the deterioration of the material in the lapped zone.

The specimens are positioned in the testing chambers with the lap horizontal, favouring the penetration of aggressive agents from the medium into the lap-joint crevice.

\subsection{Testing conditions}

The studies carried out in this respect led to a weekly cyclic test with the following configuration of stages:
- Filling the lap with distilled water, by means of exposure of the specimens for one day in a humidity condensation chamber.

- Contamination with sodium chloride of the water retained in the lap. This was carried out by exposing the specimens in a salt fog chamber. The duration of this stage can be critical in terms of anticipating the attack of the material in the lapped zone. In view of the results obtained the optimum duration is situated between 4 and $8 \mathrm{~h}$. Longer duration of this stage can lead to anticipated deterioration of the material in the non-lapped zone, while slightly accelerating the aggressiveness of the test in the lapped zone.

- Retention of the saline solution in the lap for a long time. This is achieved by placing the specimens in the interior of a climatic chamber, maintaining the temperature and relative humidity of the air at $20{ }^{\circ} \mathrm{C}$ and $95 \% \mathrm{RH}$, respectively.

- Drying of the lap, by exposure of the specimens over the weekend to the laboratory atmosphere $\left(23^{\circ} \mathrm{C}, 50 \% \mathrm{RH}\right)$.

The CENIM cycle, thus designed, led to highly satisfactory results. In comparison with the reference cycle (VDA 621-415) ${ }^{[7]}$, which follows a similar configuration, and presents the following advantages and disadvantages:

- Both tests are considered adequate for simulating in the laboratory the behaviour of materials in lapped zones.

- The VDA test is slightly more aggressive than the CENIM test (even though the former trebles the salt fog time of the latter), making it somewhat more accelerated than the CENIM test, though this does not suppose an important reduction in the number of cycles necessary for evaluating the behaviour of materials in lapjoints.

- A disadvantage which may arise in the CENIM test in comparison with the VDA test is that the former requires three chambers, while the VDA test needs only two.

\section{CONCLUSIONS}

Atmospheric exposure tests

- Given the moderate aggressiveness of the atmospheres where the study was carried out (only the atmosphere of Avilés presented 
corrosivity category $\mathrm{C} 4$ according to ISO $9223^{[10]}$, while the atmosphere of Madrid presented corrosivity category C2 (Table II)), two years of exposure has been insufficient time to cause an important level of degradation of the materials tested and, consequently, to reach definitive conclusions about their behaviour in lap-joints.

- In general, the degradation of the coatings has been greater in the lapped zone than in the non-lapped zone, the attack being initiated in the lapped zone in the vicinity of the lap openings.

- Accelerated tests

- Both cycles, CENIM and VDA, are considered adequate for simulating in the laboratory the behaviour of materials in lapped zones.

- The VDA test is slightly more aggressive, and so, more accelerated than the CENIM test. The VDA test better simulates the behaviour of materials in more aggressive atmospheres, while the CENIM test is better for atmospheres of less aggressiveness.

- A lap separation of $200 \mu \mathrm{m}$ contributes to accelerating the attack in the lap-joint with the galvanized material (painted or not). On the other hand, for the $55 \%$ Al-Zn material (painted or not) deterioration in the lap zone is accelerated when the panels are in contact by means of riveting.

\section{REFERENCES}

[1] H.E. TownsEnd, Corrosion 521 (1996) 66-71.
[2] J.P. MORAn and M.W. Egbert, Paper No. 382, Corrosion/95, NACE, Houston, USA, 1995.

[3] C.D. Hamm, Proc. $79^{\text {th }}$ Meeting of the AGARD Structures and Materials, Sevilla, España, 1994, pp. 14.1-14.11.

[4] M. Simko, S. Ban and L.A. Roudabush, Proc. Galvatech'95, Chicago, USA, 1995, pp. 611-626.

[5] T.E. DorsETT and D.D. DAVIDSON, Design of a standard test coupon for perforation corrosion, Society of Automotive Engineers (SAE), Technical Report No. 932366, 1996, pp. 403-409.

[6] ECCA Test METHOds T19-ECCA, Recommendations for panel design and method for atmospheric testing, ECCA, 1989.

[7] VDA 621-415, Prüfung des korrosionsschutzes von kraftfahrzeuglackierungen bei zyklisch wechselder beanspruchung, Frankfurt, 1982.

[8] M. Morcillo, J.A. González, E. Almeida and J.M. PUENTE, Factors influencing the corrosion behaviour of coated steel sheets in lap joints, Report 20067 EN, European Commission, Directorate-General for Research, Bruselas, 2002.

[9] B. CHICO, Tesis Doctoral, Facultad de Ciencias Químicas, Universidad Complutense de Madrid, 2001.

[10] ISO 9223, Corrosion of metals and alloys. Classification of corrosivity of atmospheres, ISO (1991).

[11] M. Morcillo, J.A. González, E. Almeida and J.M. PUENTE, Informe No.5, European Commission, DirectorateGeneral for Research, Bruselas, 2002.

[12] ASTM D 4585, Testing water resistance of coating using controlled condensation (1987).

[13] ASTM B 117, Test method for salt spray (fog) testing, ASTM, Philadelphia.

[14] DIN 50017, Klimate und ihre technische anwendung. Kondenswasser-Prüfklimate, Berlin (1982). 